\title{
II. On salt-solutions and attached water
}

\section{Frederick Guthrie}

To cite this article: Frederick Guthrie (1884) II. On salt-solutions and attached water , Philosophical Magazine Series 5, 18:110, 22-35, DOI: 10.1080/14786448408627561

To link to this article: http://dx.doi.org/10.1080/14786448408627561

曲 Published online: 29 Apr 2009.

Submit your article to this journal 주다

Џll Article views: 3

Q View related articles $₫$ 
Now, judging from available data, the normal chlorides of all triad elements melt below $510^{\circ}\left(\mathrm{BiCl}_{3}\right.$ being the highest known, melting-point $=503^{\circ}$ ), and their normal bromides below $500^{\circ}$ ( $\mathrm{BiBr}_{3}$ being the highest known, melting-point $=$ $480^{\circ}$ ). These results therefore confirm the view that beryllium is a dyad, with atomic weight $9 \cdot 2$. This is rendered still more evident by an inspection of the Plate, showing the curves of the melting-points of the halogen compounds of the elements*

\section{Fluorides.}

As fluorine is an even, whilst $\mathrm{Cl}, \mathrm{Br}$, and $\mathrm{I}$ are odd members of the seventh group, the fiuorides cannot strictly be compared with chlorides, bromides, and iodides as regards their meltingand boiling-points. The melting-points and boiling-points of the fluorides, however, taken apart from those of the other halogens, appear (if we may judge from the fow meltingpoints and boiling-points which are known) to obey laws similar to those which govern the melting-points and boilingpoints of the chlorides, bromides, and iodides.

\section{On Salt-Solutions and Attached Water. $B y$ Frederick Guthrie $\dagger$.}

\section{VIII.}

[The paragraphs are numbered in sequence with those of my memoir on Eutexia, anted, vol, xvii. p. 462.] \$232. INTRODUCTION.-When, some ten years ago, before the Physical Society, it was pointed out that the key to the temperature of any salt-ice freezing-mixture was to be found in the temperature of fusion of the cryohydrate of that salt. Since then further light has been thrown upon the subject by the discoveries and observations of others. Thus, Ditté has obtained a hydrate (probably a subcryohydrate) of hydrochloric acid, and Wroblewski has obtained a similar hydrate of carbonic acid. Pettersson, in his exhaustive study of marine ice, made in the 'Vega' expedition, has explicitly admitted that the phenomena presented by freezing and frozen sea-water can only be satisfactorily explained by the formation and properties of the cryohydrates. Though this tacit corro-

* Since writing the above, Messrs. Nilson and Pettersson (Deut. chem. Ges. Ber. xvii. p. 987) have determined the vapour-density of beryllium chloride, and find that it corresponds with the formula $\mathrm{BeCl}_{2}$, and consequently that $\mathrm{Be}=9 \cdot 2$.

+ Communicated by the Physical Society. Rend May 24, 1884. 
boration or explicit adoption by foreigners of the views I ventured to advance has given me perhaps more satisfaction than if they had been only accepted by English physicists, I may be allowed to express some regret that the latter do not yet appear to be awake to the interest and importance of the subject. It gives me, therefore, unusual pleasure to offer them this my eighth memoir on this branch of Molecular Physies.

In this memoir I shall first make a study of the ammonia group in its behaviour with water. I add a little to our knowledge of ammonia itself in this respect 'Then are examined the effects of replacing one or more of the hydrogen equivalents by ethyl. Then will be described in some detail the behaviour with water of some aniline salts.

Secondly $(\$ \$ 249-255)$, I shall shift the region of my inquiry upwards on the thermometric scale, and include in it temperatures at which the solid fuses per se, and shall thus establish the continuity of the phenomena of fusion with those of solution, making clear the fact that certain bodies, originally solid, may at high temperatures become miscible with water in all proportions. It will be shown how this latter branch of the inquiry, apart from its purely physical interest, bas a great geological one, as it throws light on the pyrohydration of igneous formations, just as the cryohydration in floes has thrown light on the formation of those masses.

233. Anmonia.-Anhydrous ammonia, $\mathrm{NH}_{3}$, according to Faraday becomes solid under a pressure of 20 atmospheres at a temperature of $-75^{\circ} \mathrm{C}$. According to Fourcroy and Vauquelin, a perfectly saturated solution (? saturated at airtemperature) freezes between $-38^{\circ}$ and $-41^{\circ} \mathrm{C}$., forming shining flexible needles; at $-49^{\circ} \mathrm{C}$. it freezes to a grey gelatinous mass.

Starting with a $33 \cdot 3$-per-cent. solution, I made solutions of various strengths, and found that pure ice separated from them at the following temperatures:-

$$
\text { Tabra XLV. }
$$

Showing Separation of Ice from Solution of Ammonia.

\begin{tabular}{|c|c|c|c|}
\hline $\begin{array}{l}\text { Per cent. of } \\
\mathrm{NH}_{3} \text {. }\end{array}$ & $\begin{array}{l}\text { Per cent. of } \\
\text { water. }\end{array}$ & $\begin{array}{l}\text { Temperature } \\
\text { of beginning } \\
\text { solidification. }\end{array}$ & $\begin{array}{c}\text { Body } \\
\text { separated. }\end{array}$ \\
\hline $\begin{array}{r}1 \\
3 \\
5 \\
10 \\
15 \\
20\end{array}$ & $\begin{array}{l}99 \\
97 \\
95 \\
90 \\
85 \\
80\end{array}$ & $\begin{array}{r}0 \\
-0.8 \\
-3.2 \\
-56 \\
-128 \\
-21.4 \\
-434\end{array}$ & $\begin{array}{l}\text { Ice. } \\
\text { ", } \\
", \\
",\end{array}$ \\
\hline
\end{tabular}


Judging by the analogy, which will appear more clear in the sequel, it seems that the body mentioned by Fourcroy is a subcryohydrate, and that the gelatinous mass mentioned still contained too little water for the cryohydrate. I find that a 33.3-per-cent. solution does not erystallize at $-80^{\circ} \mathrm{C}$.; and $I$ have as yet been unable to obtain the true cryohydrate.

$\$ 234$. Ethyl-Ammonias.-The ammonias whose relationship to water have next to be described were obtained from Kablbaum of Berlin. They were verified by means of their boiling-points, their platinum double chlorides, and by titration with standard hydrochloric acid. Those which I here employ were found to be pure.

$\S 235$. Ethylamine. Boils at $18^{\circ} \mathrm{C}$.- The solutions of this base were made by dropping an indefinite quantity into a narrow-necked weighed bottle, putting in the stopper, weighing, surrounding by a freezing-mixture, and rumning in the proper quantity of distilled water from a burette. When the quantity of water was small, it was dropped in from a capillary tube until the proper weight was reached.

The first five solutions, namely those containing $0 \cdot 99,5$, 10,15 , and 20 per cent. of ethyl-ammonia $\left(\mathrm{NH}_{2} \mathrm{C}_{2} \mathrm{H}_{5}\right)$, showed, on cooling, the separation of the easily recognizable icecrystals. On further cooling the 20-per-cent. solution, the separating crystals became opaque, betraying the cryohydrate; this occurred at $-13^{\circ} \cdot 9$, whereupon the temperature became stationary. After ten or twelve grams had solidified at $-13^{\circ} \cdot 9$, the remaining liquid was poured into a fresh tube and reduced to the same temperature. The same operation having been performed three times, the liquid was considered pure ; 3.589 grams of it were weighed in a stoppered bottle, diluted with water, over-neutralized with hydrochloric acid, evaporated in a water-bath in a platinum dish until the chloride became quite hard on cooling, heated to incipient volatilization, and weighed. There was thus obtained 1.3415 gram chloride of ethyl-ammonium or 0.7407 ethylamine, which corresponds to $20 \cdot 64$ per cent.

On cooling a stronger solution than this, solidification begins at a higher temperature, reaches a maximum between 30 and 35 per cent., and again falls, passing out of the range even of a solid carbonic-acid cryogen. As there is only one tenth of a degree difference between the points of initial solidification of the 30-and 35-per-cent. solutions, and guided by the general shape of the curve, I made a $32 \cdot 4$-per-cent. solution, and found that solidification began at $-8^{\circ} \mathrm{C}$.

It is well known that anhydrous ethylamine is not solidifiable in a solid carbonic-acid cryogen. Accordingly, the solid which 
separates from an aqueous solution of ethylamine of any and every strength between $-13^{\circ} .9$ and the anhydride is one of those remarkable bodies which I have called subcryohydrates, and which have been observed in the chloride and iodide of sodium.

The subcryohydrate of ethylamine, as a glance at the curve (fig. 1) will show, has a solidifying-point within certainly one tenth of a degree C. of $-\dot{8}^{\circ}$, and, as certainly, it has within two or three tenths of a per cent. the composition of $32 \cdot 4$ per cent. It is minutely crystalline, and of nearly the same specific gravity as the residual liquid. Its solution is eminently supersaturable, and in that state is curiously viscid. It is not easy to see a way whereby it might be made to purify itself in the act of formation. The existence of these solid hydrates of a substance which by itself resists solidification by a carbonic-acid cryogen, and the fact that their melting-points are only ten degrees or so below $0^{\circ} \mathrm{C}$., is surely an unanswerable argument that they are not mere juxtapositions of independent crystals of the two constituents.

Any horizontal line between $-13^{\circ} .9$ and $-8^{\circ}$ cuts the curve of aqueous ethylamine in three places. Within these limits, therefore, there are always three degrees of strength of the solution, which begin to solidify at the same temperature. Thus, if we find an aqueous solution of ethylamine begin to solidify at $-12^{\circ}$, we do not know whether it is of the strength 18.7 or 22.2 or 43.3 per cent. Further, it may be noted that, on adding water of the air-temperature to the solid subcryohydrate, a depression of temperature occurs to a point lower than that at which the suberyohydrate stood.

\section{TABLE XLVI.}

Separation of Solids from Aqueous Solution of Ethylamine.

\begin{tabular}{|c|c|c|c|}
\hline $\begin{array}{l}\text { Per cent. of } \\
\text { Ethylamine. }\end{array}$ & $\begin{array}{l}\text { Per cent. of } \\
\text { water. }\end{array}$ & $\begin{array}{l}\text { Temperat ure } \\
\text { at which } \\
\text { solidification } \\
\text { begins. }\end{array}$ & $\begin{array}{l}\text { Nature of } \\
\text { solid. }\end{array}$ \\
\hline $\begin{array}{l}* 0 \cdot 9901 \\
5 \\
10 \\
15 \\
20 \\
20 \cdot 64 \\
25 \\
30 \\
32 \cdot 4 \\
35 \\
40 \\
50\end{array}$ & $\begin{array}{l}99 \cdot 01 \\
95 \\
90 \\
85 \\
80 \\
79 \cdot 36 \\
75 \\
70 \\
67 \cdot 6 \\
65 \\
60 \\
50\end{array}$ & $\begin{array}{l}-\stackrel{\circ}{0} \cdot 4 \\
-2 \cdot 0 \\
=4 \cdot 7 \\
=8 \cdot 4 \\
-13 \cdot 3 \\
-13 \cdot 9 \\
-9 \cdot 5 \\
-8 \cdot 1 \\
-8 \cdot 0 \\
=8 \cdot 2 \\
-10 \cdot 1 \\
-16 \cdot 4\end{array}$ & $\begin{array}{c}\text { Ice. } \\
, " \\
", \\
\text { Oryohydrate. } \\
\text { Suberyohydrate. } \\
, " \\
, \\
" \\
" \\
"\end{array}$ \\
\hline
\end{tabular}

* Accidentally taken 1 to 100 , instead of 1 to 99 . 
§ 236. Diethylamine.-Let us now replace another equivalent of hydrogen by the same organic radical, and examine the relation towards water of diethylamine, $\mathrm{NH}\left(\mathrm{C}_{2} \mathrm{H}_{5}\right)_{2}$. This liquid boils at $54^{\circ}\left(57^{\circ}\right.$, Hofmann) at $31.02 \mathrm{~B}$. The solutions were prepared precisely as in the preceding case.

The four weakest solutions, which contained $5,10,15$, and 20 per cent. of base respectively, gave no trouble. But from this point the curve (fig. 1) descends very sharply towards the cryohydrate, and rises again with equal steepness. A 22-percent. solution yields ice on incipient solidification at $9^{\circ} \cdot 9$; while a solution containing only 1 per cent. more, a 23 -per-cent. solution, yields subcryohydrate at the same temperature of $9^{\circ} \cdot 9$. To this difficulty has to be added the circumstance that I have not met with a substance which shows so extraordinary an aptitude for supersaturation. The solutions of the subcryohydrate in the anhydrous base (all those to the right of the cryohydrate in fig. 1) and the cryohydrate itself may be cooled to $-20^{\circ}$, and diligently stirred without showing signs of solidification. The solidification may then be started by a cryogen of solid carbonic acid and ether. Moreover, the solutions near the saturated conditions are as viscid as glycerine; so that the appeal from one part of the liquid to another in the matter of crystallization, and consequent change of composition of the residual liquid, is tardy. These circumstances made it impossible to obtain the cryohydrate pure for analysis in the ordinary way by automatic purification. But they also made it unnecessary; for since a 22 per cent. gives up ice and a 23 per cent. gives up subcryohydrate at the same temperature $\left(9^{\circ} \cdot 9\right)$, it follows that a $22 \cdot 5$-per-cent solution must, within a probable error of about $0 \cdot 2$ per cent., have the composition of the cryohydrate. Having made such a solution, and cooled it to $-10^{\circ}$ in a salt-ice cryogen, the bottom of the tube containing it was dipped in a little carbonic-acid cryogen until a little white opaque regulus of crystals was formed. The whole being then restored to the ice-salt cryogen and stirred, opaque solidification began, the rounded tufts of crystals much resembling oatmeal in suspension. From first to last the temperature now remained constant at $11^{\circ} .0 \mathrm{C}$. Of course there was no need to analyse a body thus synthesized. 
TABLe XLVII.

Separation of Solids from Aqueous Solution of Diethylamine.

\begin{tabular}{|c|c|c|c|}
\hline $\begin{array}{l}\text { Per cent. of } \\
\text { Diethylamine. }\end{array}$ & $\begin{array}{l}\text { Per cent. of } \\
\text { water. }\end{array}$ & $\begin{array}{c}\text { Temperature } \\
\text { of initial } \\
\text { solidification. }\end{array}$ & $\begin{array}{l}\text { Nature of } \\
\text { solid. }\end{array}$ \\
\hline $\begin{array}{l}5 \\
10 \\
15 \\
20 \\
21 \\
22 \\
22 \cdot 5( \pm 0 \cdot 2) \\
23 \\
25 \\
30 \\
35 \\
40 \\
45 \\
50 \\
60 \\
70\end{array}$ & $\begin{array}{l}95 \\
90 \\
85 \\
80 \\
79 \\
78 \\
77 \cdot 5(\mp 0 \cdot 2) \\
77 \\
75 \\
70 \\
65 \\
60 \\
55 \\
50 \\
40 \\
30\end{array}$ & $\begin{array}{r}-1 \cdot 1 \\
2 \cdot 9 \\
5 \cdot 2 \\
8 \cdot 4 \\
9 \cdot 1 \\
9 \cdot 9 \\
11 \cdot 0 \\
9 \cdot 9 \\
9 \cdot 1 \\
8 \cdot 3 \\
8 \cdot 0 \\
8 \cdot 2 \\
8 \cdot 6 \\
9 \cdot 1 \\
12 \cdot 2 \\
23 \cdot 4\end{array}$ & $\begin{array}{c}\text { Ice. } \\
\text { ", } \\
" \\
\text { ", } \\
\text { Cryohydrate. } \\
\text { Suberyohydrate } \\
\text { ", } \\
\text { ", (pure) } \\
\text { ", } \\
\text { ", } \\
\text { ", }\end{array}$ \\
\hline
\end{tabular}

Diethylamine does not solidify in a carbonic-acid cryogen. $\S 237$. Triethylamine, $\mathrm{N}\left(\mathrm{C}_{2} \mathrm{H}_{5}\right)_{3}$. Boils at $88^{\circ}$. - Viewed as an anhydride, we should expect, à priori, to find a greater difference between the physical properties of this body and those of diethylamine than between those of the latter body and ethylamine. Indeed, the difference might be expected to be comparable with that existing between the properties of ethylamine and those of ammonia ; for the replacement of the first and the last equivalent of hydrogen by ethyl would be expected to effect a difference of kind, while the replacement of two instead of one would effect rather an alteration in degree. Be this as it may, the properties of triethylamine in reference to water are quite exceptional, or at least very remarkable. The solutions of strengths 5,10 , and 15 per cent. yielded ice; the latter and the 20 per cent. can be employed for obtaining the cryohydrate, but the 20 per cent. begins its solidification with the subcryohydrate. The soli-

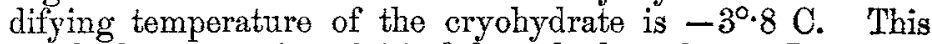
cryohydrate contains $19 \cdot 15$ of the anhydrous base. It may be remarked that the hydrochloride of this base retains hydrochloric acid with such firmness that, even when heated to incipient volatilization, it still remains acid*.

* A few grains of chloride of triethyl-ammonium heated on a hot spatula exhibit a beautiful phenomenon. The columns and whirls of white smoke can be watched petrifying in the air to white soot without much change of form. 
The suberyohydrate of this body is, like those of the previously examined ones, very prone to supersaturation; so that, in examining the richer solutions, it is advisable to have recourse to the solids of previous preparations; which act like a ferment. A nearly remelted tubeful of the subcryohydrate, set to resolidify very slowly, crystallizes in bright laminæ one or two millimetres in diameter. More quickly frozen in repose, crystalline masses an inch long are fashioned upon the glass.

\section{TABLE XLVIII.}

Separation of Solids from Aqueous Solutions of Triethylamine.

\begin{tabular}{|c|c|c|c|}
\hline $\begin{array}{l}\text { Per cent, of } \\
\text { Triethylamine. }\end{array}$ & $\begin{array}{l}\text { Per cent. of } \\
\text { water. }\end{array}$ & $\begin{array}{l}\text { Temperature } \\
\text { of initial } \\
\text { solidification. }\end{array}$ & $\begin{array}{l}\text { Nature of } \\
\text { body formed. }\end{array}$ \\
\hline $\begin{array}{l}5 \\
10 \\
15 \\
18 \\
19 \cdot 1 \\
20 \\
30 \\
40 \\
50 \\
70 \\
80\end{array}$ & $\begin{array}{l}95 \\
90 \\
85 \\
82 \\
80 \cdot 9 \\
80 \\
70 \\
60 \\
50 \\
30 \\
20\end{array}$ & $\begin{array}{l}-1 \cdot 0 \\
-20 \\
-2 \cdot 9 \\
-3 \cdot 4 \\
-38 \\
-3 \cdot 5 \\
-4 \cdot 1 \\
-5 \cdot 1 \\
-6 \cdot 7 \\
-13 \cdot 6 \\
-20 \cdot 6\end{array}$ & $\begin{array}{c}\text { Ice. } \\
, " \\
", \\
\text { Oryohydrate. } \\
\text { Subcryohydrate. } \\
", \\
" \\
" \\
" \\
"\end{array}$ \\
\hline
\end{tabular}

For the curve, see fig. 1, p. 31 .

$\$ 238$. Triethylamine is one of those rare bodies which, like sulphate of sodium, sulphate of calcium, caustic lime, and a few others, are more soluble in cold than in hot water. The behaviour of the three bodies named is clearly traceable to the decomposition by heat of definite hydrates. Without laying undue stress upon this, it seems that the phenomenon in question is one of decomposition, which so often follows increased temperature, and not an inversion of the rule that solubility also increases with temperature. The body decomposed in the case before us is clearly a hydrate-either the cryo- or subcryohydrate. Accordingly, though striking in its presentation, the phenomenon is really quite continuous with the decomposition by heat of oil of vitriol; which decomposition, I presume, does actually take place when that liquid is heated above its boiling-point (in a closed vessel). But while in the latter case the products of decomposition are probably miscible, and mix, though held apart from chemical union by heat-tension; with the hydrates of ethylamine the products of thermal decomposition are separated not only chemically but in mass, becanse, when ehemically separated, they are not molecularly miscible, at least in all proportions. 
The following table shows the temperatures at which turbidity begins and ceases in aqueous solutions of triethylamine of various strengths. (See also fig. 1, "Triethylamine and Water as liquids.")

\section{TABLE XLIX.}

Separation in Aqueous Solutions of Triethylamine.

\begin{tabular}{|c|c|c|c|}
\hline $\begin{array}{l}\text { Per cent. of } \\
\text { Triethylamine. }\end{array}$ & $\begin{array}{l}\text { Per cent. of } \\
\text { water. }\end{array}$ & $\begin{array}{c}\text { Critical } \\
\text { temperature } \\
\text { between clearness } \\
\text { and turbidity. }\end{array}$ & Remarks. \\
\hline 1.96 & $98 \cdot 04$ & $7 \stackrel{\circ}{8}\{$ & Becomes clouded, and be- \\
\hline $\begin{array}{l}3 \cdot 85 \\
5 \\
8 \\
10 \\
15 \\
18 \\
20 \\
30 \\
40 \\
46 \cdot 46 \\
50 \\
70 \\
80 \\
90 \\
94 \cdot 5\end{array}$ & $\begin{array}{l}96 \cdot 15 \\
95 \\
92 \\
90 \\
85 \\
82 \\
80 \\
70 \\
60 \\
53 \cdot 54 \\
50 \\
30 \\
20 \\
10 \\
5 \cdot 5\end{array}$ & $\begin{array}{l}41 \\
34 \\
23 \cdot 5 \\
21 \cdot 3 \\
18 \cdot 8 \\
18 \cdot 6 \\
18 \cdot 6 \\
18 \cdot 2 \\
18 \cdot 4 \\
18 \cdot 3 \\
18 \cdot 4 \\
17 \cdot 1 \\
13 \cdot 4 \\
6 \cdot 1 \\
-7 \text { (about) }\end{array}$ & \\
\hline & 1 & & $\begin{array}{l}\text { Complete liquid solubility } \\
\text { at all temperatures. }\end{array}$ \\
\hline
\end{tabular}

A solution containing only 0.99 per cent., sealed in a very strong glass tube and heated to $200^{\circ} \mathrm{C}$., did not show any opalescence.

A 1.96-per-cent. solution begins to give off bubbles of gas at the same temperature at which it becomes turbid. A still more dilute solution, namely a 0.99 per cent., does not become turbid at $200^{\circ} \mathrm{C}$., when it is heated in a sealed tube. The curve (fig. 1, "Triethylamine and Water as liquids") shows the relationship above examined. The following example illustrates the history of a solution. Ten grams of ethylamine and 90 grams of water, shaken together at $25^{\circ}$, form a white emulsion. On standing at that temperature, two transparent layers are formed, of which the upper is ethylamine saturated at $25^{\circ}$ with water, and the lower water saturated at $25^{\circ}$ with ethylamine. On heating to $28^{\circ}$, both layers become turbid; the upper sheds water saturated at $28^{\circ}$ with ethylamine, which falls, and the lower ethylamine saturated at $28^{\circ}$ with water, which rises. These new quantities join their respective camps, the constitution of which has, of course, been altered by the 
departures, and is now that of saturation at the new temperature in the two cases. The surface of demarcation shifts towards the centre of the mass. Similar effects follow further rises of temperature. Let now the tube cool. The former condition is reestablished. On further cooling, the surface of demarcation shifts-rises in this case as the two liquids mix more with one another. At $21^{\circ} .3$ perfect solution ensues, and this is well marked within a tenth of a degree. Just above this temperature the mass is opalescent, just beneath it it is perfectly limpid. When at this critical temperature, the warmth of the hand only momentarily applied makes a wide test-tube of the limpid mixture quite milky. Nor can such a test-tube be passed so nimbly through a flame as not to exhibit the same change. Following the temperature downwards, we find the solution remains clear below $0^{\circ}$, until we reach $-2^{\circ}$, whereupon crystals of ice appear. These increase with the falling temperature until $-3^{\circ} .8$ temperature and $10 \cdot 1$ per cent. is reached. The cryohydrate now solidifies, and no further percentage change is possible; nor temperature change, until solidification is complete.

A 40-per-cent. ratio only shows perfect mixture at $18^{\circ} .4$. It remains a mixture until $-5^{\circ \cdot 1}$, whereupon subcryohydrate begins to appear in the solid form. Its quantity goes on increasing with lowering temperature until $-20^{\circ} \cdot 6$ is reached: this marks an 80-per-cent. solution. At still lower temperatures no doubt the liquid becomes more enriched. If the anhydrous liquid is unsolidifiable by cold, then the ordinate at 100 per cent. is asymptotic; but if, as is more likely, the liquid is solidifiable, the remainder of the water and of the ethylamine will unite to form some hydrate even lower than the subcryohydrate at some very low but constant temperature. An 80-per-cent. ratio at $-30^{\circ}$ is thick with solid subcryohydrate. Perfect liquefaction takes place at $-20^{\circ} \cdot 6$. The liquid remains clear until $+12^{\circ}$ is reached. At and above $12^{\circ}$ separation ensues, which increases with the increasing temperature. The curve (fig. 1, "Triethylamine and Water as liquids") is virtually a straight line between 15 per cent. and 50 per cent. The deviations are probably errors of observation; and these errors of observation are certainly not due to want of definition of the occurring and vanishing turbidity, which is well marked within 0.025 of a degree. Nor are they due to errors of original weighing or change during manipulation; for the very fatness of the curve shows that a great change of composition has little effect upon the temperature of saturation. If they are indeed errors, they arise probably from the collecting together of the opalescing globules into 
clear drops which separate down, leaving the liquid above as clear as though it had been cleared by cold. The indication from a gradually ascending temperature is accordingly more to be relied on than one from a falling temperature.

When water is added to triethylamine, but little heat is evolved. A very small rise in temperature occurs when the 30-per-cent. mixture is made. The constituents should be brought to about $10^{\circ}$; and in the final experiment the thermometer and thin glass bulb, in which the mixture is effected, are to be previously warmed fully to the temperature at which

Fig. 1.

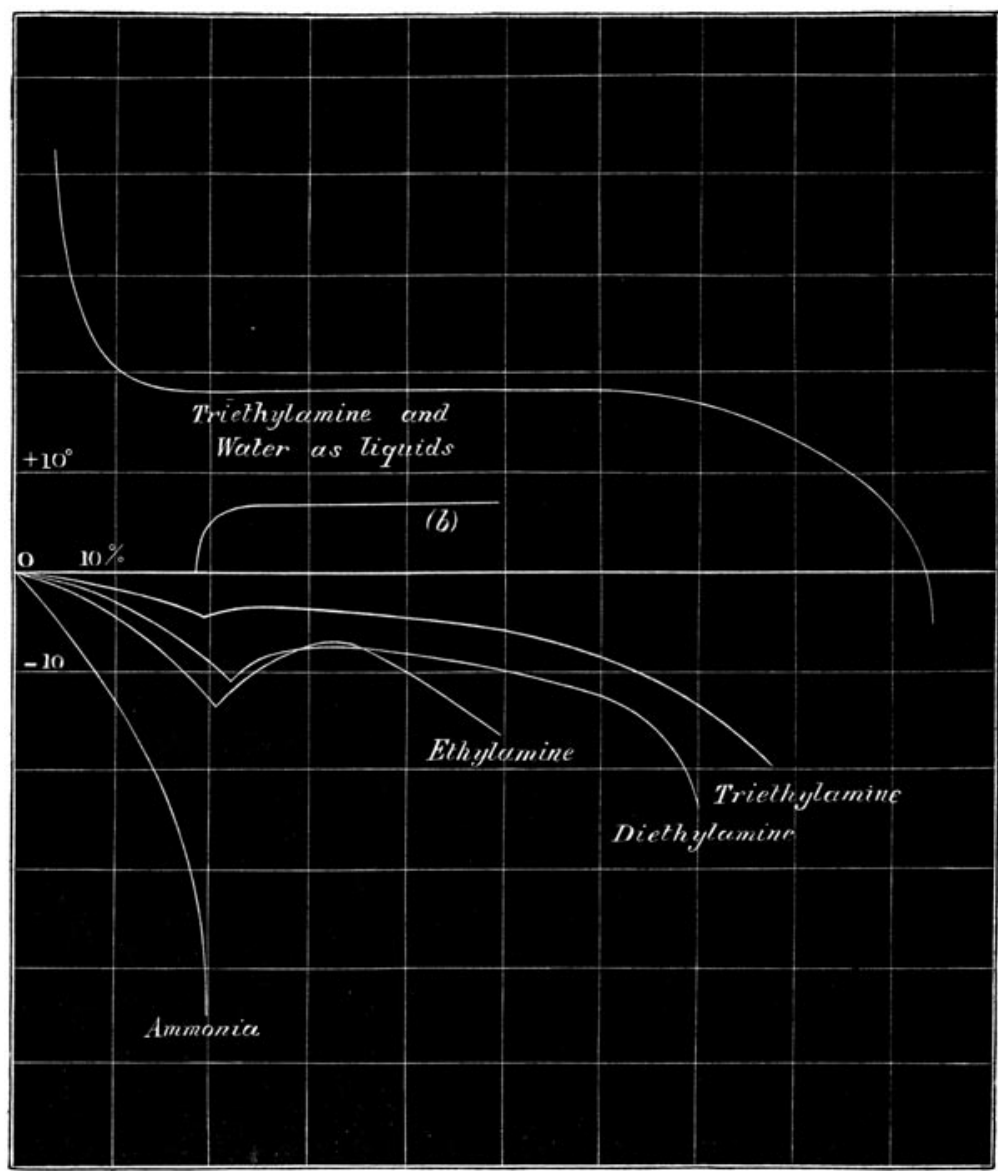

they stood at the end of the previous experiment. It is probable that the smallness of the heat of combination is nearly 
connected with the ease of thermal separation. It is to be noticed, moreover, that in the region of the lower curve about the subcryohydrate, where the curve is flat because great change of percentage makes little difference in temperature of initial solidification, the curvature of the upper curve, fig. 1 , "Triethylamine and Water as liquids," is also nearly nothing. Whether above or below zero, we are dealing apparently at every individual percentage with the same substance, the suberyohydrate: it is this region which is so keenly sensitive to changes of temperature.

$\S 239$. There is this important and essential difference between the genesis of a cryohydrate and that of a subcryohydrate. Solutions of nearly the cryohydrate strength approach the composition of that body as they lose heat and sink in temperature-weaker ones by the shedding of water (as ice), stronger ones by the shedding of salt or subcryohydrate. And this is true for all solutions from 0 per cent. up to the strength of the suberyohydrate; that is, on the curve, to the point where $\frac{d x}{d y}$ changes sign.

Not so with the subcryohydrate. A solution weaker than the subcryohydrate, to the left of it on the figure, will " run down " to the cryohydrate by dint of shedding the subcryohydrate. A solution stronger than the suberyohydrate will "run down" to the solidifying-point of the anhydrous liquid or to that of some secondary cryohydrate, no example of which is, I think, yet known. In either case, the liquid residue gets further and further away from the ratio in the subcryohydrate. The whole condition may be illustrated by the motion of a marble rolling upon the curve. It will run down to the bottom of the valley of the cryohydrate wherever it is placed on the slopes of that valley, and there remain in stable equilibrium. But placed upon the top of the great swell of the subcryohydrate, it will be at rest only if undisturbed, and so be in instable equilibrium. It will, if disturbed, either roll down to the bottom of the cryohydrate valley, or roll into the abyss of the anhydrous liquid. The cryohydrate is the level of a lake. The suberyohydrate is the watershed (subcryohydrate shed) of a hill-range.

The cryohydrate being an eutectic alloy, the subcryohydrate is a definite chemical combination, existing probably as such in the liquid when above zero, and liberating in its formation the heat observed when the two liquids are mixed; and as, for instance, sulphate of soda crystallizing either from an acid or alkaline solution leaves the liquid more acid or more alkaline than before, so the subcryo- 
hydrate in its solidification leaves the liquid from which it separates continuously more aqueous or less aqueous according as it started from a solution more or less aqueous than itself. The "more" and "less," as here employed, refer of course to intensity, not to quantity, and the change is the analogue of that suffered by electricity when the surface of a conductor alters in size.

\$240. Some Applications of the above Property of Triethylamine.-It appears from Table XLIX. that one weight of triethylamine with 19 weights of water is a ratio requiring $34^{\circ}$ $\mathrm{C}$., or $93^{\circ} .5 \mathrm{~F}$., that is a low blood-heat, to effect its turbidity. A ratio of 1 of ethylamine and 24.76 of water requires $\leq 1^{\circ} \mathrm{C}$. or $105^{\circ} .8 \mathrm{~F}$. for the same effect to be produced: this is a te rer heat. Accordingly, a few little glass capsules containing s,lutions of the triethylamine of strengths graduated between these two and thereabouts, and containing also a little mercury to assist the stirring-up when shaken, may be of use in the diagnosis of fever. The eye may be fastened to a thread or rod, and so introduced beneath the arm or into the cavities. I have made a series of 9 such capsules, which show turbidity at $\mathrm{F}$.

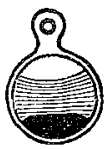
$68^{\circ} \cdot 3,69^{\circ} \cdot 4,76^{\circ} \cdot 1,79^{\circ} \cdot 9,91^{\circ} \cdot 4,98^{\circ} \cdot 6,105^{\circ} \cdot 2,111^{\circ} \cdot 2,123^{\circ} \cdot 8$. $\$ 241$. The radiation from an electric arc passing into an 8-per-cent. solution will warm it to opacity. Thin strips of variously coloured glass placed in such solutions will determine the opalescence after various time lapses,- the red glass acting the slowest, and the others, speaking broadly, the quicker the shorter the wave-length of the light they transmit. Two of complementary colour, which together absorb all radiation, or a single black one, act the quickest. Coloured glasses placed between the solution and the source of radiation cause opalescence in times which are the longer the shorter are the transmitted wave-lengths.

A few drops of the solution placed as a thin film between two thin sheets of flat glass, and prevented from evaporation by sulphur-cement around the edges, forms a sensitive plate. The hand placed upon it leaves a white silhonette. The spectrum thrown upon this plate leaves a transient record.

It is probable that the heat liberated when triethylamine is mixed with water is, if the expression may be allowed, the real image of the heat which on entering the mixture effects separation. They are both equal in quantity to the heat of subcryohydration; the former being that heat itself. It is a happy circumstance that the temperature at which separation begins within the limits of 20 to 50 per cent. solutions is a usual atmospheric temperature, namely $18^{\circ} \cdot 3 \mathrm{C}$. $\left(64^{\circ} .94 \mathrm{~F}_{2}\right)$.

Phil. Mag. S. 5. Vol. 18. No. 110. July 1884. 
$\$ 241$ a. The quantitative relationship in respect to solubility existing between water and triethylamine was determined with considerable accuracy in the following manner. A 50 c. c. burette graduated to two-tenths was sealed at one end, and the mercury and water-meniscus values determined. It was drawn out to a narrow neck, and received about 2 e.c. of mercury. The whole being now counterpoised, a few c.c. of ethylamine were introduced, which proved to weigh $6 \cdot 86$ grams. $\Delta$ few grams of water were next added, the end sealed off and dried, and the whole reweighed. It was found that 7.885 grams of water were present.

The whole was now bronght to a temperature low enough to ensure perfect mixture, and then gradually heated in a large beaker of water to which successive portions of warmer water were added. The water was diligently stirred. When the temperature is high enough to cause separation, the tube is kept at that constant temperature for half an hour, being repeatedly shaken. Taking the level of the mercury as constant, and calling it, when corrected for meniscus, 0 , we have first the height of the plane of separation of the two liquids to read off. This requires no correction for meniscus at temperatures below $25^{\circ} \mathrm{C}$. At $30^{\circ}$ and $50^{\circ}$ there is some + cur vature (like water); this I have neglected. The height of the upper surface has to be read and corrected for meniscus. (For this the same correction is taken as for water.) The volume of water at $15^{\circ}$ was $7.88 \mathrm{c.c}$., and the volume of triethylamine was 9.5 c. c. On bringing the two together, sufficient heat was set free by the mixture of part to prevent the mixture of the whole. On cooling to $15^{\circ}$ the two mixed perfectly, and the volume was $16 \cdot 6$, showing therefore a contraction of $0.8 \mathrm{c}$. c. At $18^{\circ} \cdot 3$ the liquid still remained clear, but at $18^{\circ} \cdot 7$, that is in half a degree, a great separation had occurred. In the following table the corrected readings are given.

Separation between water and triethylamine (Triethylamine 46.45 per cent., Water 53.55 per cent.).

\begin{tabular}{|c|c|c|c|}
\hline At & & $\begin{array}{l}\text { Vol. of lower } \\
\text { stratum. }\end{array}$ & $\begin{array}{l}\text { Vol. of upper } \\
\text { stratum. }\end{array}$ \\
\hline $15^{\circ} \cdot 0$ & • &.$\quad 0$ & $16 \cdot 6$ \\
\hline $18 \cdot 3$ & . & 0 & $16 \cdot 6$ \\
\hline $18 \cdot 7$ & . . & . 3.5 & $13 \cdot 2$ \\
\hline $19 \cdot 0$ & . . & . . 4.5 & $12 \cdot 2$ \\
\hline $20 \cdot 0$ & . . & . $\quad 6 \cdot 1$ & $11 \cdot 4$ \\
\hline $21 \cdot 0$ & . . & . . 6.8 & $10 \cdot 1$ \\
\hline $22 \cdot 0$ & . & . $7 \cdot 2$ & $9 \cdot 7$ \\
\hline $25 \cdot 0$ & . & . $7 \cdot 8$ & $9 \cdot 3$ \\
\hline $30 \cdot 0$ & . & $\cdot 7 \cdot 3$ & $9 \cdot 4$ \\
\hline $50 \cdot 0$ & . . & . $8 \cdot 0$ & $9 \cdot 7$ \\
\hline
\end{tabular}


So nearly complete is the separation at $25^{\circ}$, that above this temperature the apper stratum gives mure in volume by expansion by heat than it loses by the rise of the plane of demarcation. To get an idea of the completeness of the separation at $50^{\circ} \mathrm{O}$., we may compare the volume of the lower stratum at $50^{\circ}$, which is 8.0 , with that of $7 \cdot 885$ grams of water at $50^{\circ}$, which is 7.93 . This signifies that at $50^{\circ}$ the lower stratum must be nearly pure water, and the upper nearly pure ethylamine. For the plane of separation stands only 80 of the height of the original water-column above that height. See fig. 1 , curve $b$.

[To be continued.]

\section{On the Electric Discharge in Gases. By Eulhard Wiedemann.**}

\section{[Plate ir.]}

$I^{\mathrm{N}}$ a number of previous communicationst I have investigated the behaviour of gases under the influence of electric discharges in various ways. The present research is a continuation of those investigations, and is concerned with (1) the effect upon the phenomena of interposing resistances between the poles of the machine and the electrodes of the discharge-tube; (2) the phenomena obtained with different distances between the electrodes; (3) measurements of the heating effect upon the gas at different points of the discharge ; (4) deflection of the positive discharge; (5) the behaviour of the discharge under the influence of the magnet; $(6)$ the examination of an hypothesis as to the nature of the kathode-rays, as well as (7) the nature of the positive discharge and the stratifications; (8) further observations on the influence of the magnet; (9) behaviour of bad conductors as kathodes; (10) connexion of the potential of the discharge with the form of the electrodes; and (11) remarks on the management of electrophoric machines.

The great complexity of the problem explains why the separate phenomena have not been hitherto sharply distinguished from each other, as, for example, the "glow" appearing at somewhat higher pressures, the kathode-rays which are formed at lower pressures, \&c.

* Translated from the Annalen der Physik und Chemie, vol. xx. p. 756 (1883), with additions and colrections by the Author.

+ Wied. Ann. v. p. 200 (1878); vi. p. 298 (1879); ix. p. 157 (1880); x. p. 202 (1880); Plil. Mag. vol. x. p. 35̃7. The glass apparatus has been made for the experiments by Herr Götze. 